\author{
Luiza KOSTECKA-TOMASZEWSKA, PhD \\ Faculty of Economics and Management, University of Bialystok \\ e-mail: 1.kostecka@uwb.edu.pl \\ ORCID: 0000-0003-0205-1437
}

DOI: $10.15290 /$ oes.2018.04.94.14

\title{
ECONOMIC SECURITY OF CHINA: THE IMPLICATIONS OF THE BELT AND ROAD INITIATIVE ${ }^{1}$
}

\begin{abstract}
Summary
Goal - The aims of the research are to identify the most significant internal and external factors affecting the economic security of China and assess the importance of the Belt and Road Initiative for China's future development.

Research methodology - In order to organize internal and external determinants of economic security of China, SWOT (strengths, weaknesses, opportunities and threats) analysis was applied. Moreover, an important element of the research process was an attempt to verify hypothesis that the Belt and Road Initiative is a key instrument of China's economic security strategy.

Score - China has transformed from a poor rural country into one of the main economic powers as a result of the economic reforms initiated in the late 1970s. However, we can observe that the economy of China is slowing down. In order to ensure economic security and maintain a stable economic growth as well as avoid the middle income trap China has introduced the Belt and Road Initiative. Since its announcement, the concept has been gradually gaining in importance and has finally become the key instrument of the Chinese foreign policy and a major element of economic development strategy. The main motive behind this project is to develop transport and energy infrastructure which will allow China to gain access to natural resources and new markets. An efficient transport network will facilitate trade, while energy infrastructure will prevent problems with energy and resource supply, which the Chinese economy needs. The Belt and Road Initiative is a way of boosting economic development of China through improving infrastructure from Asia to Africa and Europe and the establishment of trade links among all partner countries. The New Silk Road concept aims to use the advantages of the Chinese economy and the states participating in the initiative to stimulate its economic growth. Therefore, it is a strategy of providing long-term economic security.

Originality/value - The paper raises the issue of the Chinese economic security understood as a long-term ability of the economy to achieve a relatively fast and sustainable economic growth. In this paper, the author defines the concept of economic security and with the help of SWOT analysis presents the strengths and weaknesses of China's economy as well as opportunities and possible threats to its stability. Moreover, the paper includes comprehensive analysis of China's motives behind the Belt and Road Initiative in the context of economic security of China.
\end{abstract}

Key words: China, Chinese economy, Belt and Road Initiative, economic security

JEL classification: O53, O19, F02

1 The paper was prepared on the basis of a presentation on Economic Security of China in 21st Century: SWOT Analysis presented at the 35th International Scientific Conference on Economic and Social Development: Sustainability from an Economic and Social Perspective which was held 15-16 November 2018 in Lisbon, Portugal. 


\section{Introduction}

China belongs to the fastest growing economies in the world, with a significant economic, demographic, and military potential as well as a growing international position. Within one generation China has transformed from a poor rural country into one of the main economic powers. Furthermore, during the 2008 economic crisis China's economy was one of the few which continued growing. However, nowadays we are witnessing an economic slowdown, because the current engines of growth are slowly losing their power to drive the Chinese economy. China needs new growth impulses to maintain stable economic growth and avoid the middle income trap. In order to overcome middle income trap and to sustain economic growth Xi Jinping has introduced the Belt and Road Initiative. This initiative comprises the land-based Silk Road Economic Belt and the sea-based 21st Century Maritime Silk Road. The Belt and Road Initiative is an ambitious long-term strategy focused on infrastructure development, promotion of broadly understood connectivity and integration between Asia, Europe and Africa. Since its announcement, the concept has been gradually gaining in importance and has finally become the key instrument of the Chinese foreign policy and a major element of economic development strategy. The aims of the paper are to identify the most significant internal and external factors affecting the economic security of China and assess the importance of the Belt and Road Initiative for China's future development.

\section{Essence and measurement of economic security}

Economic security of the state is one of the main elements of the national security system. It gained a special significance after the global economic crisis in 2008 . Economic security has many definitions. It is most frequently defined as a state that guarantees smooth development of the national economy (table 1). The chance to achieve the desired status of a country's economic security should be mainly seen in internal strengths and consistently and wisely pursued an economic policy. At the same time it should be noted that the level of economic security is not stable and is likely to change. Therefore, only the ability to use strengths of the economy and external opportunities, at the same time dealing with weaknesses and threats coming from the international environment, will guarantee economic security in the long term perspective.

Considering table 1, it should be noted that there is no generally accepted definition of economic security. Still, it is possible to identify certain features that provide an overall picture of what this concept means. Economic security should be understood as the ability of the economy to achieve a relatively fast and sustainable economic growth and create favourable conditions for raising the level of broadly understood well-being of citizens under free trade and free flow of factors of production (especially the capital in the form of foreign direct investment). It should be emphasized that at the current stage of development of the world economy it is impossible to ensure economic security and overcome developmental barriers across 
the country or region. Moreover, it often requires taking global action. Although the shape of the economic security strategy still largely depends on internal factors such as economic policy, amount and structure of natural resources, capital as well as human resources. Economic security of a given country is also dependent on the international economic and political situation, relations with neighbours and membership in international economic, political and military structures.

TABLE 1

\section{Overview of the definitions of state economic security}

\begin{tabular}{|c|c|}
\hline Author & Essence of economic security \\
\hline $\begin{array}{l}\text { B. Buzan } \\
{[1991]}\end{array}$ & $\begin{array}{l}\text { economic security concerns access to the resources, finance and mar- } \\
\text { kets necessary to sustain acceptable levels of welfare and state power }\end{array}$ \\
\hline $\begin{array}{l}\text { M. Perczyński } \\
{[1990]}\end{array}$ & $\begin{array}{l}\text { the susceptibility of a country to negative changes in its economic } \\
\text { environment, including external political and economic attempts to } \\
\text { destabilise its socio-political system, development, and defence } \\
\text { capability }\end{array}$ \\
\hline $\begin{array}{l}\text { Z. Stachowiak } \\
\text { [1994] }\end{array}$ & $\begin{array}{l}\text { a state of national economy, which ensures its highly effective fun- } \\
\text { ctioning through the proper use of internal development factors and } \\
\text { the ability to effectively oppose external pressure, which can disturb } \\
\text { its development }\end{array}$ \\
\hline $\begin{array}{l}\text { Z. Kołodziejak } \\
{[1996]}\end{array}$ & $\begin{array}{l}\text { the ability of a state's economic system to use internal development } \\
\text { factors and international economic co-relations in a way which would } \\
\text { guarantee its undisturbed development }\end{array}$ \\
\hline $\begin{array}{l}\text { E. Haliżak } \\
\text { [1997] }\end{array}$ & $\begin{array}{l}\text { situation in which the economy can develop, generate incomes and } \\
\text { savings for investment, and in which there are no external dangers } \\
\text { which can disturb the economy }\end{array}$ \\
\hline $\begin{array}{l}\text { Y. Jiang } \\
\text { [2007] }\end{array}$ & $\begin{array}{l}\text { the ability to provide a steady increase in the standard of living for the } \\
\text { whole population through national economic development while } \\
\text { maintaining economic independence }\end{array}$ \\
\hline $\begin{array}{l}\text { R. Włoch } \\
\text { [2009] }\end{array}$ & $\begin{array}{l}\text { a situation which guarantees economic conditions necessary for sur- } \\
\text { vival, prosperity, and balanced social development within the borders } \\
\text { of a given state, as well as for the preservation and efficient } \\
\text { functioning of the state's institutions }\end{array}$ \\
\hline $\begin{array}{l}\text { K.M. Księżopolski } \\
\text { [2011] }\end{array}$ & $\begin{array}{l}\text { the undisturbed functioning of the economy - preserving its basic } \\
\text { development indicators and a comparative balance with the econo- } \\
\text { mies of other countries }\end{array}$ \\
\hline $\begin{array}{l}\text { K. Raczkowski } \\
{[2012]}\end{array}$ & $\begin{array}{l}\text { relatively balanced, internally and externally, state of functioning of the } \\
\text { national economy, where the risk of occurring imbalances is kept } \\
\text { within acceptable organisational and legal norms and principles of } \\
\text { social coexistence }\end{array}$ \\
\hline
\end{tabular}

Source: own elaboration.

Economic security of the state is a complex and multidimensional issue. It encompasses various issues which are essential for economic development and 
for the existence of a state. Thus, it should be analysed not only from an economic point of view but also from a political, legal, military, demographic, social, technological and environmental perspectives [Księżopolski, 2011; Mkrtchyan, 2015; Reznikova, 2016]. Since economic security includes many components, its measurement is a complex issue. Moreover, it refers not only to current situations but also to future situations, making its measurement much more difficult.

\section{Internal and external determinants of China's economic security}

China has transformed from a poor rural country into one of the main economic powers as a result of the economic reforms initiated in the late 1970s. The government understood that the country cannot develop in economic isolation and that in order to accelerate the pace of development it is necessary to engage in international trade and obtain foreign direct investments. The sources of the success of China's economy can be found first and foremost in the government's effectively implemented economic policy aiming to integrate China with the world's economy, the use of foreign capital to modernise the national economy and the use of the comparative advantage in the form of unlimited cheap labour resources [Kostecka, 2009]. For many years, the Chinese export-oriented model of development based on FDI and the exports of labour-intensive goods with low added value has been effective. China has become the world's largest exporter and holder of foreign exchange reserves as well as one of the largest importers and exporters of foreign capital in the form of FDI. Moreover, it has developed at an impressive rate which was unattainable for the world's largest economies [WTO, 2018; IMF, 2018; UNCTAD, 2018; World Bank, 2018]. China is an undisputed leader in the global economy in terms of the gross domestic product (GDP) dynamics. Since 1978, it has been the fastest growing country in the world with the average annual GDP growth rate approaching 10\%. However, we can observe that the economy of China is slowing down. China's annual GDP growth rate dropped from the average rate of $9.6 \%$ in the period 1978-2017 to $6.9 \%$ in 2017 [World Bank, 2018].

It should be stressed that the slowdown in the Chinese economy is not only the result of a deterioration in global economy, but also of serious structural problems which the Chinese economy has struggled with for years. The economic growth mechanism, which relies on the availability of cheap labour and low production costs, exporting labour-intensive products of low added value, artificial undervaluation of the yuan, foreign direct investment, foreign technologies and intense inward investment loses its effectiveness and cannot guarantee a sustainable growth of the economy in the long term [Kostecka, 2009].

The global financial crisis has shown that the dependence of the Chinese economy on foreign markets proved to be too high and risky. As the global economic situation deteriorated leading to a decrease in exports and foreign direct investments, the economic growth in China has slowed down visibly. In order to control overheating and overcome the crisis, the Chinese authorities tried to change 
its development strategy to be less dependent on exports and more based on internal consumption. They used different economic tools to increase the domestic demand. The anti-crisis measures implemented by the government, among others, included measures that affect employment (new infrastructural investments thanks to which new jobs were created) and the country's social situation (e.g. lower taxes, social assistance) [Kostecka, 2011]. However, the most important component of China's stimulus package was the investment in infrastructures, especially in railways, roads, and airports which helped to avoid the surge of mass unemployment for migrant workers which were under the threat as a result of the collapse of the external demand. Though the stimulus program was effective to overcome crisis, one of its lasting side effects was the creation of massive excess capacity in many industrial sectors (e.g. steel, cement, aluminium, etc.). It should be stressed that if, in the long run, China fails to change its growth model through structural adjustments, it will not be able to sustain its growth. From a macroeconomic point of view, China needs to lower its investment rate. Due to the fact that investment rate in China has been increasing further, it has deepened the problems related to overcapacity. Initially, overcapacity was overcome by investing more. However, more investment creates more overcapacity for the future [Yu, 2009]. In the future, if the government fails to tackle structural problems, and if the growth of domestic consumption fails to increase significantly, it will be difficult to absorb the overcapacity.

The results of China's stimulus program were impressive. Thanks to huge stimulus package and extensive stimulus measures implemented by the government, China began to recover from the global economic recession quicker than any other major economy. However, the 2007/2008 global financial crisis revealed a serious weakness of the export-oriented and FDI-driven growth model applied by China [Kostecka, 2011]. In the early 1980s, China became attractive for foreign direct investment (FDI) which helped restart the economic growth. Over the course of time, China became an open economy involved in the global value chains (GVCs), highly dependent on exports. Becoming a part of the GVCs is an important step towards economic development, but to achieve a sustainable economic growth not only should developing countries increase their participation in the GVCs but also move them up. Thus, in order to stimulate growth and competitiveness China needs to climb the global value chain ladder and move toward high-tech industries.

Within the last four decades foreign direct investments flowing into China have played a significant role in the economic growth, because they provided the Chinese economy with access to finances, advanced technologies or modern management methods. However, the influx of cheap labour-seeking FDI perpetuates the current development model. Thus, the hitherto model of development, based on low labour costs and access to cheap resources is disadvantageous in the long run and cannot be the basis of permanent economic security and prosperity, and can even strand China in the middle income trap. The adopted model of development is also burdened with high risk, because the increase in wages reduces competitiveness and attractiveness of the market for foreign capital. Therefore, low wages and cost-based competition have become an essential structural problem for the Chinese economy 
and it requires immediate in-depth reforms, the lack of which is going to prevent China from joining the group of the highly developed economies. It should be stressed that FDI flowing into China and the focus on exports are not what the economy needs and may entrench a disadvantageous economic structure, which may be a threat to future development. At the current stage of China's economic development, the inflow of each foreign direct investment has lost its significance. Much more important from the point of view of economic development is the quality of the investment and the level of technological advancement. In the longterm perspective, it is possible to induce the changes in the structure of the economy by targeting investments at the desired areas of production. Therefore, the policies to attract foreign investors should be more selective.

TABLE 2

\section{Overview of strengths and weaknesses of China's economy}

\begin{tabular}{|c|c|}
\hline & es \\
\hline 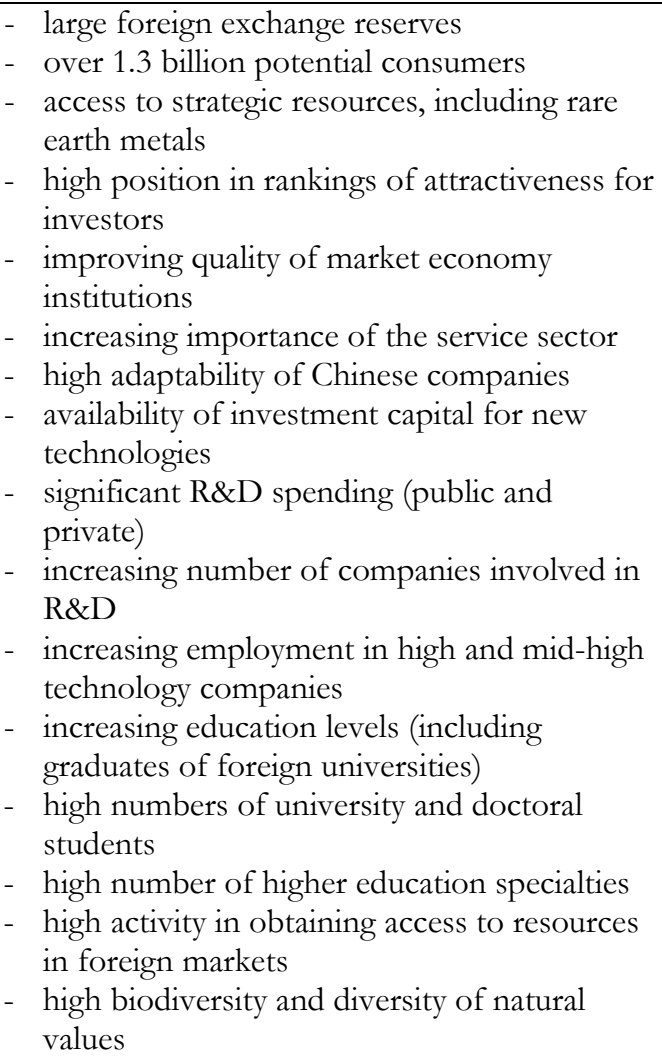 & 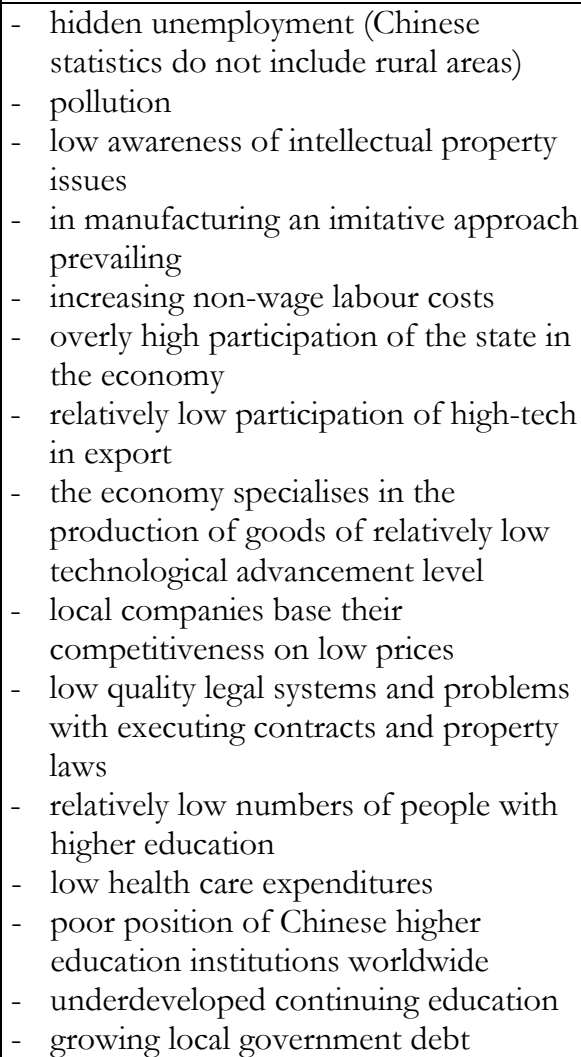 \\
\hline
\end{tabular}

Source: author's own compilation based on the literature review and own research. 
TABLE 3

\section{Overview of economic opportunities and threats to the economic security of China}

\begin{tabular}{|c|c|}
\hline Opportunities & Threats \\
\hline $\begin{array}{l}\text { - influx of foreign direct investment } \\
\text { - } \text { increasing competitiveness of Chinese } \\
\text { companies, which can compete with } \\
\text { foreign businesses both in China and in } \\
\text { international markets } \\
\text { - } \text { investment expansion during the crisis } \\
\text { and access to strategic assets; China is one } \\
\text { of the largest outbound direct investors in } \\
\text { the world } \\
\text { - increasing numbers of university students } \\
\text { - improving adaptation of universities to } \\
\text { the needs of the labour market } \\
\text { - investments in China's own R\&D sector } \\
\text { - increasing willingness of global companies } \\
\text { to build high-tech centres in China } \\
\text { - creating Chinese R\&D centres and } \\
\text { technology parks helps improve } \\
\text { innovation in economy } \\
\text { - decreasing technology gap } \\
\text { - increasing environmental awareness } \\
\text { - expansion of economy based on a } \\
\text { sustainable development paradigm } \\
\text { - biofuel production, alternative energy } \\
\text { sources } \\
\text { - as response to an ageing population China } \\
\text { expanded its former one-child policy to a } \\
\text { limit of } 2 \text { children per family in } 2015 \\
\text { - opportunities arising from the Belt and } \\
\text { Road Initiative } \\
\text { - Made in China } 2025 \\
\text { - to boost domestic consumption and } \\
\text { leisure spending China has begun } \\
\text { implementing an official policy for a } 4.5 \text { - } \\
\text { day work week }\end{array}$ & 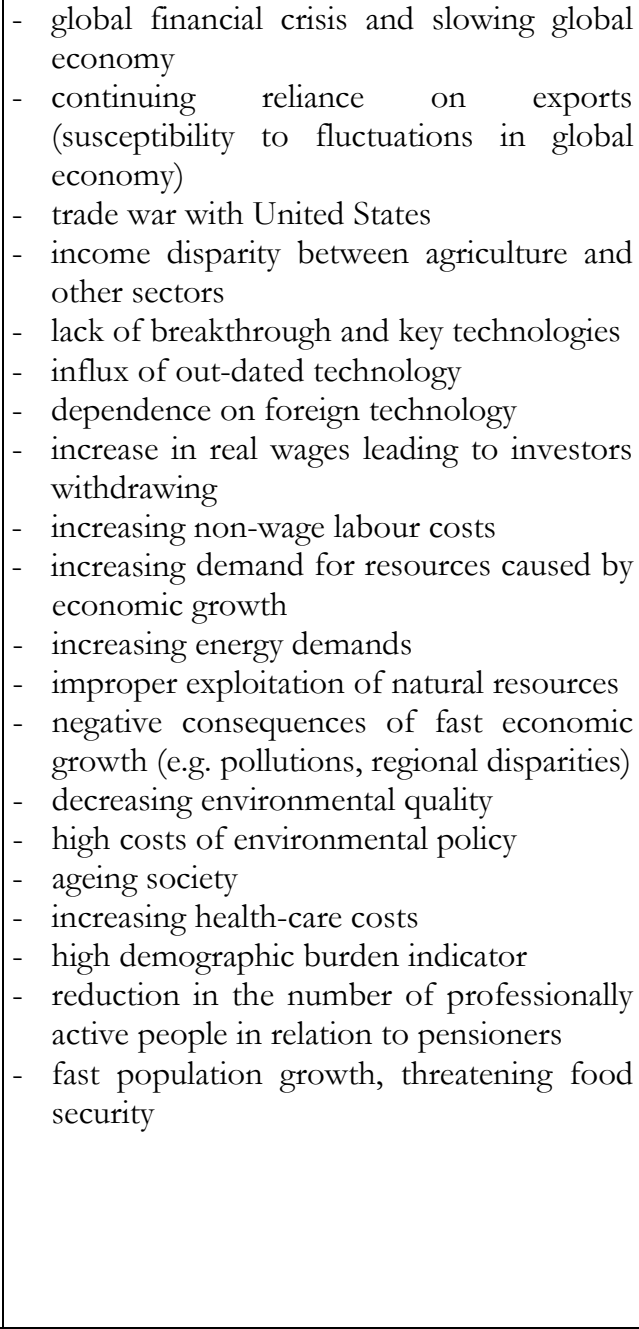 \\
\hline
\end{tabular}

Source: author's own compilation based on the literature review and own research.

Over the last 40 years China has achieved a significant increase of the GDP and higher level of competitiveness. Moreover, a development gap between China and high income countries has been steadily decreasing. However, the past success does not guarantee the future success. There are a number of factors which can have a negative influence on the economic security of China. The analysis of the weaknesses of China's economy presented in table 2 and possible threats to its stability 
presented in table 3 suggests that economic development in China is facing a turning point with many similarities to the countries which have fallen into the middle income trap [Eichengreen et al., 2011; Felipe et al., 2012]. On the other hand, there are also many factors (strengths and opportunities presented in table 2 and 3) allowing China to enjoy undisturbed economic growth in the future and perhaps avoid the middle income trap and join the highly developed world economies.

In order to retain stable economic growth and avoid the middle income trap China needs new impulses to stimulate its economic growth. China's government understands the importance of creating new drivers for economic growth. That is why, China has gradually changed its development strategy. In order to stay on its path towards development China continues economic reforms and modifies its development model: from a resource intensive model to a more sustainable one, from a model based on imported technology to technological innovation, from a model based on low-value-added manufacturing to high-value-added manufacturing, from an export-led growth model to the one based on domestic demand, from a foreign investment based model to the one based on the export of capital [Hangbo, 2008; Kostecka, 2012]. Moreover, in order to overcome the middleincome trap and to sustain economic growth Xi Jinping has introduced the Belt and Road Initiative (BRI).

\section{The Belt and Road Initiative as a key instrument of China's economic security strategy}

The concept of the New Silk Road was proposed in 2013 by President of China $\mathrm{Xi}$ Jinping. The main objective of the initiative is to create a network of land (the Silk Road Economic Belt) and sea (the 21st Century Maritime Silk Road) transport corridors linking China with all the countries of Asia, Europe and Africa which are willing to participate in the project. In the beginning, China did not indicate the geographical framework of the project and did not provide any concrete plans of the routes, emphasizing at the same time that the cooperation in modernization of the existing infrastructure and the construction of a new infrastructure will enable the intensification of economic relations and the economic growth of all the countries lying along the New Silk Road [China's Initiatives ..., 2015].

From the map published on the official website of the Chinese news agency Xinhua, it appears that the Belt and Road project can cover dozens of countries (see map 1). The presented version of the route shows one variant of the land section and one variant of the sea section, which merge with each other in Northern Italy. However, it should be emphasized that this is a big simplification, because in reality the concept of the New Silk Road does not mean the creation of a specific route from point A to point $\mathrm{B}$ but the network of trade routes consisting of several complementary options [Kaczmarski, 2015]. The initiative is open and any state which expresses the willingness and readiness to cooperate in the implementation of the goals can join it. China has invited all countries to join the cooperation and has 
been waiting for proposals from potential partners. This approach seems reasonable, because the countries interested in the cooperation are able to prepare a project internally coherent and integrated with the transport network of the neighbours [Tarnawski et al., 2016, pp. 84-85]. It should be pointed out that the BRI has received great support from the side of international community since its announcement. In the course of time the concept has been gradually gaining in importance and has finally become the key instrument of the Chinese foreign policy and a major element of the economic development strategy.

\section{Map of the Belt and Road Project}

MAP 1

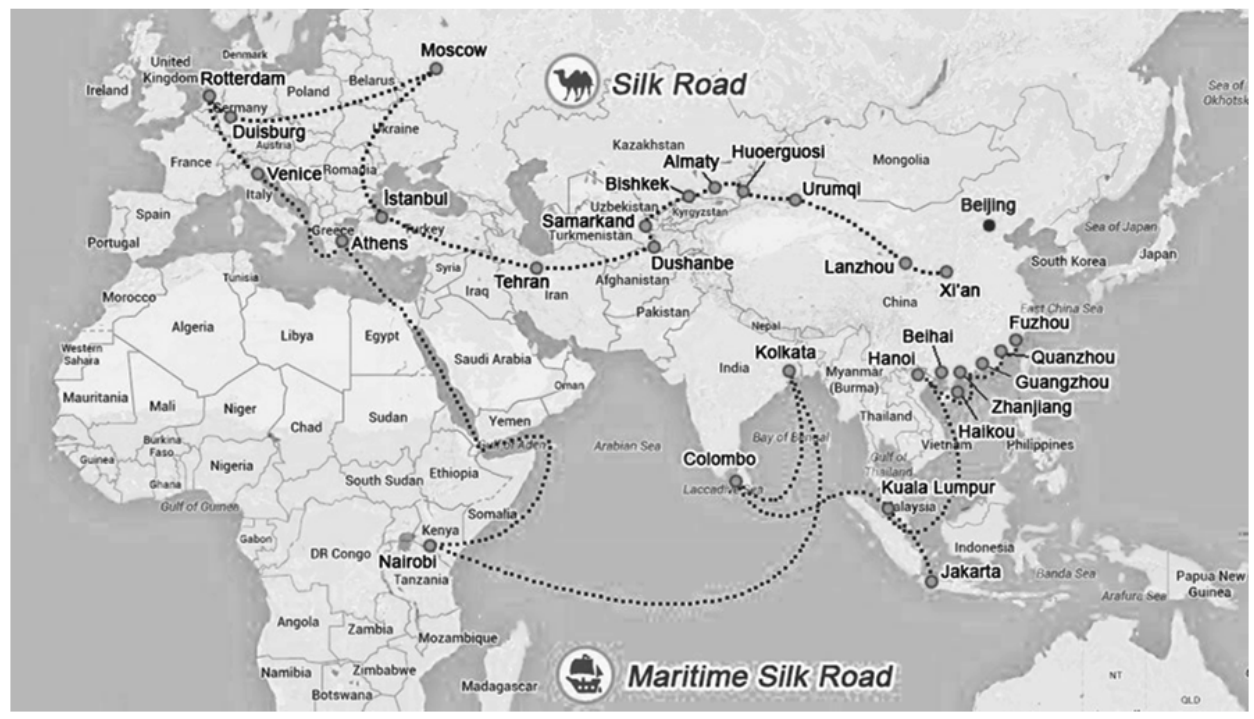

Source: [China's Initiatives ..., 2015].

According to the Vision and Actions on Jointly Building the Silk Road Economic Belt and the 21st-Century Maritime Silk Road (the Vision and Actions Plan) issued in 2015, the priority areas of cooperation between the belt-road countries include political dialogue, infrastructure development, trade and investment enhancement, financial integration and the development of people-to-people contacts [Vision and Actions ..., 2015]. The cooperation at these areas will stimulate economic growth and bring multi-dimensional benefits for all the countries involved in the project. The Belt and Road Initiative is a response to China's internal economic problems. It is actually a way for boosting economic development of China through improving infrastructure from Asia to Africa and Europe and the establishment of trade links among all partner countries. 


\section{China's motives behind the Belt and Road Initiative}

CHART 1
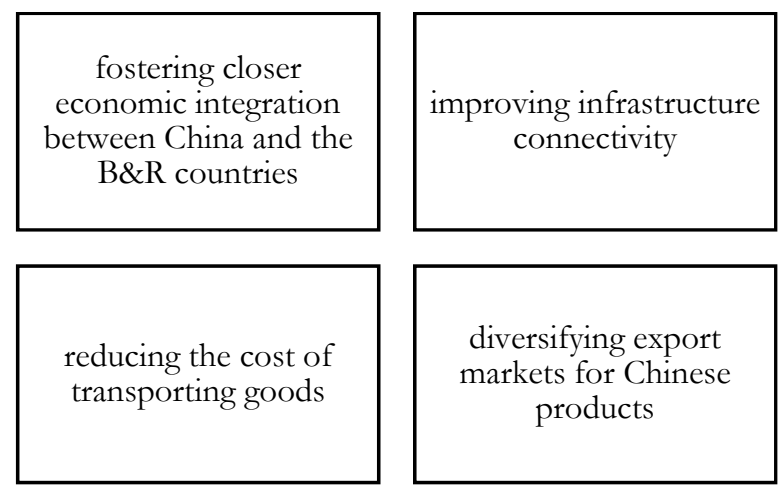

expanding markets for

Chinese industries

(including those with

domestic overcapacity)
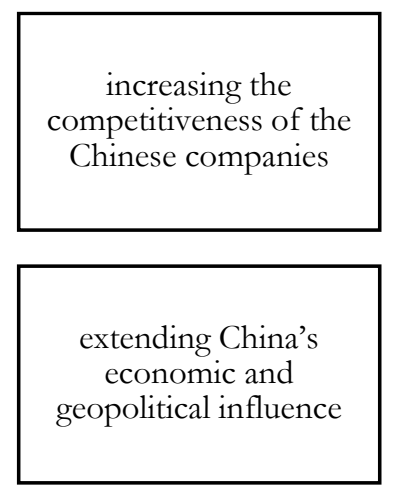
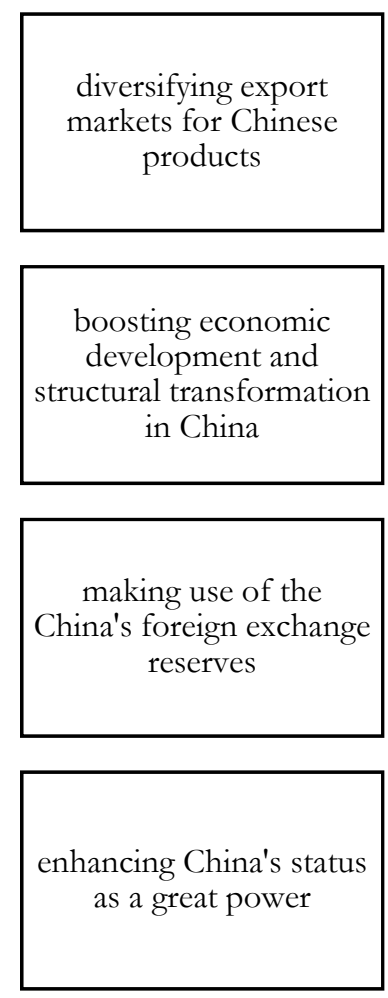

enhancing new trade and investment opportunities abroad

enhancing China's energy security through diversification of import sources

enhancing the development of China's underdeveloped regions

reducing dependence of the China's economy on maritime trade

enhancing China's hard and soft power

Source: own elaboration on the basis of the literature review and own research.

The Belt and Road Initiative has the potential to yield considerable economic and political gains for China. Many of these have been explicitly stated by the Chinese authorities. The official rationale behind the Belt and Road Initiative is that economic growth and development of international trade can be accelerated through stronger connectivity and infrastructure development will help reduce transport times and costs. There is also a full set of more self-interested Chinese economic motives including the promotion of the Renminbi (RMB) as an international currency and developing of impoverished Chinese inland provinces. However, many of the potential benefits of the BRI are less publicly articulated. These implicit objectives which are even more important to China include: sustaining economic growth, ensuring secure access to export markets and strategic 
resources, diversifying export markets and promoting the Chinese overseas investment, seeking an outlet for the Chinese excess production capacity and moving up the global value chains (chart 1).

The main focus of the BRI is to facilitate economic connectivity and foster much closer economic integration across Asia and between Asia and Europe through infrastructure connectivity. The development of infrastructure is a key objective of the BRI and is largely a prerequisite for effective further cooperation and connectivity improvements. Enhancing connectivity involves removing bottlenecks and providing missing links in existing transportation routes, building port facilities, and improving intermodal operation [Enright et al., 2016]. China aims to develop not only transportation infrastructure (railways, expressways, tunnels, bridges, air routes and airports, land and sea ports, transshipment terminals, etc.) but also energy infrastructure (oil and natural gas pipelines, power plants, etc.) and telecommunication infrastructure throughout the $\mathrm{B} \& \mathrm{R}$ region to facilitate free movement of goods, raw materials, information and people between the partner countries [Vision and Actions ..., 2015]. By connecting all of the belt-road economies together and creating an extensive network of infrastructure in which all roads lead to China, China will become a central part of the BRI. Better developed infrastructure will facilitate trade exchange, improve access to foreign markets for the Chinese goods and ensure energy security through diversification of import sources. Moreover, the development of land route of the Belt and Road project will help to reduce the dependence of the Chinese economy on maritime trade. It should be emphasized that the majority of exports as well as a considerable part of China's imports, including strategic resources such as oil and iron ore, are transported by ships. An estimated $85 \%$ of China's imports and between $70-85 \%$ of its energy supplies pass through several maritime chokepoints such as the Strait of Malacca in the South China Sea which is secured by the USA. China's overreliance on energy supplies by maritime transport routes, which are vulnerable to potential interdiction by foreign navies, is so-called the Malacca dilemma [European Parliament, 2016]. That is why, the energy and transport security is very important component of the BRI. China wants to secure transport routes and energy supplies by creating the Maritime Silk Road and building up new pipelines across the BRI countries. The Maritime Silk Road will enable to increase China's influence over shipping and port operations throughout the belt-road region. An alternative routes will facilitate trade, while energy infrastructure will prevent problems with energy and resource supply, which the Chinese economy needs.

Moreover, as the world's trade power, China's main interest is to ensure markets for its goods and to reduce the costs of transporting goods. China seeks to access new markets in order to maintain stable growth during its transition from an exportdriven and investment-led economy to one more based on domestic consumption and services. In order to enhance trade and investment opportunities, China aims to reduce trade and investment barriers, lower trade and investment costs, and promote regional economic integration [Vision and Actions ..., 2015]. Consequently, better connections and trade facilitation and the resulting reductions in transaction 
costs are expected to increase international trade and foster economic growth of both China and the other countries along the routes.

China's foreign trade with countries along the New Silk Road has seen rapid growth in recent years. In 2017, the total imports and exports of China and the Belt and Road countries increased 13.4 percent year on year to $\$ 1440.32$ billion. China's trade with countries covered by the Belt and Road Initiative accounted for 36.2 percent of the country's total foreign trade. Moreover, in 2017 China's imports from those countries grew faster than exports for the first time [Big data shows ..., 2018].

The Belt and Road Initiative also gives an opportunity to partially absorb China's massive excess industrial capacity in steel, cement and other industrial inputs because the construction of new transport facilities in Asia will stimulate demand for the Chinese construction material, construction company services and highvalue manufactured goods [European Parliament, 2016]. However, the BRI does not entirely solve the problem of overcapacity. China continues to rely on the existing investment-led growth model but is now investing abroad instead of in the domestic market [Shepard, 2017; Yu, 2018]. In order to solve the problem of overcapacity China's authorities want to move the excess production capacity out of country. China has a lot of surplus equipment for making steel, cement and pleat glass for the Chinese market and wants companies to move the whole production facilities outside country through direct foreign investment to countries that need building equipment and materials to build their infrastructure. These goods should be produced locally where they are needed [Cai, 2017]. Moreover, the Chinese companies which decide to move production out of China can take advantage of lower labour costs elsewhere in neighbouring countries and next use the newly built infrastructure to facilitate exports back to China. China has to move up the global value chain and at the same time relocate its labour-intensive industries to countries with cheaper wages. The BRI opens up such opportunities as many countries in the belt-road region have the abundant labour supply. Moving factories with excess capacity to the countries along the belt and road helps China reduce its overcapacity while helping less developed countries to build up their industrial bases [Cai, 2017]. Thanks to this China helps countries at an early stage of development to industrialise and simultaneously China undergoes industrial upgrading and structural transformation of its economy.

China's plan to export excess capacity is combined with a going out strategy. The Belt and Road Initiative may be even understand as a new version of the going out strategy launched in the late 1990s. In 2000, the Chinese government initiated the Go Global policy, which encourages the Chinese companies to take up operations in foreign markets in order to acquire strategic resources, necessary in the process of industrial upgrading, structural transformation and economic growth. The objective of the government is to increase the level of China's outward FDI, because it is considered as an important tool in supporting the economic development of the country. The Chinese government actively supports outgoing FDI through financial incentives, technical support, and economic diplomacy. The Belt and Road Initiative builds off previous Go Global Initiative. This time, however, the initiative appears 
to have gained a much stronger impulse with a better-shaped conceptual framework and significant dedicated funding. In particular, the endeavour is backed by financial infrastructure involving multiple sources such as the Silk Road Fund, the Asian Infrastructure Investment Bank, the New Development Bank of BRICS [Adarov, 2018].

In 2017, the Chinese companies invested in 57 countries along the New Silk Road. The Belt and Road countries attracted $\$ 20.17$ billion China's outward foreign investment flows accounting for $12,7 \%$ of total amount of the Chinese OFDI. The investment mainly went to Singapore ( $\$ 6.3$ billion), Kazakhstan ( $\$ 2.1$ billion), Malaysia ( $\$ 1.7$ billion), Indonesia ( $\$ 1.7$ billion), Russia ( $\$ 1.5$ billion), Laos $(\$ 1.2$ billion), Thailand ( $\$ 1.1$ billion), Vietnam ( $\$ 0.7$ billion), Cambodia ( $\$ 7.7$ billion), Pakistan ( $\$ 0.7$ billion) and United Arab States ( $\$ 7.7$ billion). In the past five years, China has invested a total of $\$ 80.73$ billion in the countries along the New Silk Road. By the end of 2017, China's outward direct investment stock in countries along New Silk Road had reached $\$ 154.40$ billion, accounting for $8.5 \%$ of the total. Top ten countries in terms of the stock were Singapore, Russia, Indonesia, Kazakhstan, Laos, Pakistan, Myanmar, Cambodia, United Arab Emirates and Thailand [Statistical Bulletin ..., 2018].

The launching projects under the umbrella of the Belt and Road Initiative will not only facilitate Chinese companies to invest overseas but also enable China to extend its influence through trade, investment and finance across Asia, Europe and Africa. This economic expansion may finally result in the Chinese dominance over the economies of many countries [Czerewacz-Filipowicz, Konopelko, 2017, p. 347]. Currently, the Belt and Road Initiative is an important instrument of China's economic as well as foreign policy. It is a response to two multilateral trade and investment agreements with the participation of the United States, namely the Transatlantic Trade and Investment Partnership (TTIP) between the European Union and the United States and Trans-Pacific Partnership (TPP) an agreements between the United States and selected Asian and Pacific countries (i.e. Australia, Brunei, Chile, Japan, Canada, Malaysia, Mexico, New Zealand, Peru, Singapore and Vietnam) with excluding China. Due to the implementation of the belt and road projects, China will gradually enhance its political as well as economic influence in the regions covered by the BRI (e.g. by financing infrastructure projects or taking over international companies of key importance) at the expense of the United States and the European Union countries, while avoiding confrontation and open conflict [Tarnawski et al., 2016, p. 87].

Furthermore, the BRI is an opportunity to making use of the China's foreign exchange reserves by investing abroad and offer loans to developing countries. China possessing sizable surpluses in foreign exchange reserves is inclined to spend a part of them to finance this brand new concept. The Belt and Road Initiative is expected to boost greater capital flows overseas from China which results in a further internationalization of the RMB [PwC Growth Markets Centre, 2017]. In the process of internalization of the RMB, more and more enterprises began using the $\mathrm{RMB}$ in cross-border business in order to avoid the risks of exchange rates and 
promote profits. Additionally, with the aim of financing projects where the Chinese currency is used in loans, China in 2015 joined the European Bank for Reconstruction and Development, and founded the Asian Infrastructure Investment Bank. These steps yielded success, and the International Monetary Fund added the renminbi to the basket of global currencies [Djankov, 2016]. The RMB was officially included in SDR currency basket in 2016, which strengthened the status of the RMB as a global reserve currency.

And last but not least China's self-interested motive behind the Belt and Road initiative is the need to reduce economic disparities between prosperous eastern coastal provinces and less developed western inland areas. It is expected that the BRI will contribute to the development of China's lagging provinces by connecting them with neighbouring countries and involving them into the global value chains. The Vision and Actions Plan points out that, in the process of implementing the initiative, China is planning to make full use of the comparative advantages of its various regions, strengthen cooperation among the eastern, western and central regions as well as comprehensively improve the openness of the Chinese economy [Vision and Actions ..., 2015]. The Belt and Road Initiative is expected to contribute to the development of underperforming provinces, and closing the gap between these provinces and well developed coastal provinces.

\section{Conclusions}

Guaranteeing long-term economic security is a priority for the economic policy of any state. The effectiveness of any strategy of building economic security is largely dependent on recognising and optimising the utilisation of internal and external conditions. In 2018, China is celebrating the 40th anniversary of its reforms and opening-up which has led to the spectacular growth and impressive reduction of poverty. Over the past 40 years, the Chinese strategy of ensuring economic security has been successful. China has undergone tremendous changes from a centrallyplanned to market economy that have transformed an impoverished country into an economic power. Currently, the Chinese economy is an unattainable role model for many developing countries. However, we can observe that the economy of China is slowing down, because the sources which were the foundation of the growth are slowly losing their driving power. In order to ensure economic security in the long run and maintain a stable economic growth as well as avoid the middle income trap China has introduced the BRI. It should be stressed that the main motive behind the Chinese Belt and Road initiative is to develop transport and energy infrastructure which will allow China to gain access to natural resources and new markets. An efficient transport network will facilitate trade, while energy infrastructure will prevent problems with energy and resource supply, which the Chinese economy needs. The New Silk Road concept aims to use the advantages of the Chinese economy and the states participating in the initiative to stimulate its economic growth. Therefore, it is a strategy of providing long-term economic security. 


\section{References}

Adarov A., 2018, China's Belt and Road Initiative: opportunity or threat0?, The Vienna Institute for International Economic Studies, https://wiiw.ac.at/china-s-beltand-road-initiative-opportunity-or-threat--n-338.html [date of entry: 30.10.2018].

Big data shows B\&R cooperation yields win-win results, 2018, Belt and Road Portal, https://eng.yidaiyilu.gov.cn/qwyw/rdxw/56375.htm [date of entry: 30.10.2018].

Buzan, B., 1991, New Patterns of Global Security in the Twenty-First Century, "International Affairs", vol. 67, no. 3, DOI: 10.2307/2621945.

Cai P., 2017, Understanding China's Belt and Road Initiative, Lowy Institute for International Policy, https://www.jstor.org/stable/resrep10136 [date of entry: 30.10. 2018].

China's Initiatives on Building Silk Road Economic Belt and 21st-Century Maritime Silk Road, 2015, Xinhua News Agency, http://www.xinhuanet.com/english/special/silkroad/index.htm [date of entry: 15.09.2018].

Chow, G., 2015, China's economic transformation (edition 3), Wiley-Blackwell, Hoboken.

Czerewacz-Filipowicz K., Konopelko, A., 2016, Regional Integration Processes in the Commonwealth of Independent States: Economic and Political Factors, Springer, Cham.

Djankov, S., 2016, The Rationale Behind China's Belt and Road Initiative, [in:] China's Belt and Road Initiative: Motives, Scope and Challenges, Djankov S., Miner S. (eds), Washington, DC: Peterson Institute of International Economics, pp. 1-35, https:// piie.com/system/files/documents/piieb16-2_1.pdf [date of entry: 30.10.2018].

Eichengreen B., Park D., Shin K., 2011, When Fast Growing Economies Slow Down: International Evidence and Implications for China, "NBER Working Paper", no. 16919, DOI: $10.3386 /$ w16919.

Enright, Scott \& Associates, 2016, One Belt One Road: Insights for Finland, https:// www.marketopportunities.fi/china-one-belt-one-road-creating-opportunities-forfinnish-companies [date of entry: 30.10.2018].

European Parliament, 2016, One Belt, One Road (OBOR): China's Regional integration initiative, http://www.europarl.europa.eu/thinktank/en/document.html? reference=EPRS_BRI(2016)586608 [date of entry: 30.10.2018].

Felipe J., Abdon A., Kumar U., 2012, Tracking the Middle-Income Trap: What is it, Who is in it, and Why?, "Working Paper", no. 715, Levy Economics Institute, https:// ssrn.com/abstract $=2049330$ [date of entry: 5.10.2018].

Haliżak E., 1997, Ekonomiczny mymiar bespieczeñstwa narodowego i międzynarodowego, [w:] Bespieczeństwo narodowe i miedzynarodowe u schytku XX wieku, Bobrow D.B., Haliżak E., Zięba R. (red.), Wydawnictwo Naukowe Scholar, Warszawa.

Hangbo W., 2008, Rzecrywistość i perspektymy rožnoju gospodarczego Chin, [w:] Chiny w globalnym swiecie, Pomykało W. (red.), Fundacja Innowacja, Warszawa.

IMF, World Economic Outlook Database, 2018, https://www.imf.org/external/ pubs/ft/weo/2018/02/weodata/index.aspx [date of entry: 21.10.2018].

Jiang Y., 2007, Economic Security: Redressing Imbalance, "China Security", vol. 3, no. 2, pp. 66-85. 
Kaczmarski M., 2015, Nowy Jedwabny Szlak: uniwersalne narzedzie chinskiej polityki, https://www.osw.waw.pl/pl/publikacje/komentarze-osw/2015-02-10/nowyjedwabny-szlak-uniwersalne-narzedzie-chinskiej-polityki [date of entry: 15.09.2018].

Kołodziejak Z., 1996, Bezpieczeństwo ekonomiczne - geneza, uwarunkowania, zakres pojeciowy, aktualnośc, [w:] Bezpieczeństwo ekonomiczne we wspótczesnym swiecie, FrejtagMika E., Kołodziejak Z., Putkiewicz W., Wydawnictwo Politechniki Radomskiej, Radom.

Kostecka L., 2009, Sytuacja gospodarcza Chin i jej perspektywy, „Prace Naukowe Akademii Ekonomiczej w Katowicach", s. 101-112, http://yadda.icm.edu.pl/yadda/element/bwmeta1.element.ekon-element-000171219199 [date of entry: 5.10.2018].

Kostecka L., 2011, Chiny wobec wspótczesnego kryzysu gospodarczego, [w:] Gospodarka a polityka na proykładzie państw azjatyckich, Marszałek-Kawa J. (red.), Wydawnictwo Adam Marszałek, Toruń.

Kostecka L., 2012, Konkurencyjnośc gospodarki a naptyw beapośrednich inwestycji zagranicznych na pryyktadzie Chin (unpublished doctoral dissertation), Uniwersytet w Białymstoku, Białystok.

Księżopolski K.M., 2011, Bezpieczeństwo ekonomiczne, Elipsa, Warszawa.

Lin J., 2014, The Quest for Prosperity: How Developing Economies Can Take Off, Princeton University Press, Princeton.

Mkrtchyan T.M., 2015, State Economic Security System and Its Components, http:// dx.doi.org/10.15242/ICEHM.ED915 [date of entry: 27.09.2018].

Perczyński M., 1990, Globalne uwarunkowania bezpieczeństwa ekonomicznego, Polski Instytut Spraw Międzynarodowych, Warszawa.

PwC Growth Markets Centre, 2017, Realising opportunities along the Belt and Road, https://www.pwc.com/gx/en/growth-markets-centre/assets/pdf/pwc-gmcrepaving-the-ancient-silk-routes-web-full.pdf [date of entry: 30.10.2018].

Raczkowski K., 2012, Percepcja bezpieczeństwa ekonomicznego i wyzwania dla zarzqdzania nim w XXI wieku, [w:] Bezpieczeństwo ekonomiczne. Wyzwania dla zarzqdzania państwem, Raczkowski K. (red.), Wolters Kluwer, Warszawa.

Reznikova N., 2016, Ecological imperatives for extension of globalization processes: problem of economic security, "Інвестиціi: практика та Аосві^" no. 21, http://www.investplan.com.ua/pdf/21_2016/6.pdf [data wejścia: 27.09.2018].

Shepard W., 2017, The Real Reason Behind What's Driving China's Ambitions For A New Silk Road, "Forbes", https:/ /www.forbes.com/sites/wadeshepard/2017/10/13/ chinas-hunger-for-energy-resources-is-whats-driving-the-belt-and-road/\#1d667 b4a67ef, [date of entry: 30.10.2018].

Stachowiak Z., 1994, Bezpieczeństwo ekonomiczne, [w:] Ekonomika obrony, Stankiewicz W. (red.), AON, Warszawa.

Statistical Bulletin of China's Outward Foreign Direct Investment, 2018, Ministry of Commerce of People's Republic of China.

Tarnawski M., Zaleski P., Kostecka-Tomaszewska L., 2016, Rola mocarstw w stosunkach miedzynarodowych, Texter, Warszawa.

UNCTAD statistics, https://unctad.org/en/Pages/statistics.aspx [date of entry: 27.09.2018]. 
Vision and Actions on Jointly Building Silk Road Economic Belt and 21st-Century Maritime Silk Road, 2015, National Development and Reform Commission, Ministry of Foreign Affairs, and Ministry of Commerce of the People's Republic of China, http://en.ndrc.gov.cn/newsrelease/201503/t20150330_669367.html [date of entry: 15.09.2018].

Włoch R., 2009, Bezpieczeństwo ekonomiczne państwa, [w:] Bezpieczeństwo państwa, Wojtaszczyk K.A., Materska-Sosnowska A. (red.), Oficyna Wydawnicza ASPRA-JR, Warszawa.

World Bank Database, http://data.worldbank.org/indicator/NY.GDP.MKTP. KD.ZG [date of entry: 15.09.2018].

WTO Statistics Database, http://stat.wto.org/Home/WSDBHome.aspx?Language $=\mathrm{E}$ [date of entry: 5.10.2018].

Wübbeke J., Meissner M., Zenglein M.J., Ives J., Conrad B., 2016, Made in China. The making of a high-tech superpower and consequences for industrial countries, Mercator Institute for China Studies (MERICS), https://www.merics.org/sites/default/ files/2017-09/MPOC_No.2_MadeinChina2025.pdf [date of entry: 30.10.2018].

Yu J., 2018, The belt and road initiative: domestic interests, bureaucratic politics and the EUChina relations, "Asia Europe Journal”, vol. 16(3), pp. 223-236. DOI: 10.1007/ s10308-018-0510-0.

Yu Y., 2009, China's Reaction to the Global Economic Crisis, Research Institute of Economy, Trade and Industry, https://www.rieti.go.jp/en/rieti_report/112.html [date of entry: 30.10.2018]. 